Tumour necrosis factor $-\alpha(T N F-\alpha)$ is a major proinflammatory cytokine inducing the synthesis and release of many inflammatory mediators. It is involved in immune regulation, autoimmune diseases, and inflammation. Our previous study demonstrated that acan thoic acid, (-)-pimara-9(11), 15-dien19-oic acid, a pimaradiene diterpene isolated from Acantbopanax koreanum, inhibited TNF- $\alpha$ production. To extend our understanding of inhibitory effects of acanthoic acid on TNF- $\alpha$ production, its effects on TNF- $\alpha$ gene expression was tested. Based on the results from RT-PCR and promoter analys is of TNF- $\alpha$, it was found that acanthoic acid suppressed TNF- $\alpha$ gene expression. But the same concentration of acanthoic acid had no effect on IL-6 gene expression. Haptoglobin is an acute phase protein which is induced by TNF- $\alpha$. When liver cells were treated with acan thoic acid, haptoglobin synthesis was blocked by acanthoic acid. These data confirmed that acanthoic acid inhibited gene expression and biological function of TNF- $\alpha$.

Key words: Acanthoic acid, TNF- $\alpha$, Haptoglobin

\section{Effects of acanthoic acid on TNF- $\alpha$ gene expression and haptoglobin synthesis}

\author{
H-S. Kang, H. K. Song, J-J. Lee, K-H. Pyun and \\ I. Choi ${ }^{\mathrm{CA}}$
}

Immune Cell Signal Transduction Research Unit and Natural Product Biosynthesis Research Unit Korea Research Institute of Bioscience and Biotechnology, KIST, PO Box 115, Taejon 305-600, Republic of Korea

${ }^{\mathrm{CA}}$ Corresponding Author

Tel: $(+82) 0428604223$

Fax: (+82) 0428604593

\section{Introduction}

Tumour necrosis factor- $\alpha$ (TNF- $\alpha$ ) is produced by many different types of cells including activated macrophages and fibroblasts. It has diverse effects on the target cells including inducing cytotoxicity to L929 cells, stimulating fibroblast cell proliferation, and increasing $\mathrm{PGE}_{2}$ and arachidonic acid production. ${ }^{1-3}$ TNF- $\alpha$ is also involved in many immune diseases such as rheumatoid arthritis, ${ }^{4}$ sepsis, immunodeficiency, ${ }^{5}$ insulin-dependent diabetes mellitus ${ }^{6}$ and inflammation. The regulation of TNF- $\alpha$ production is critical in the maintenance of homeostasis of the immune system and in the prevention and treatment of the immune diseases.

Acanthoic acid, (-)-primara-9(11), 15-dien-19-oic acid, is a diterpene isolated from the root bark of Acanthopanax koreanum, which has been traditionally used as a tonic and sedative as well as in the treatment of rheumatism and diabetes in Korea. ${ }^{7}$ Previous studies ${ }^{8,9}$ using this diterpenoid compound demonstrated that it inhibited TNF- $\alpha$ production by human monocytes/macrophages and in the sera of silicosis model. Also, its oral administration into the mice significantly reduced the writhing syndrome induced by acetic acid and it reduced leukotriene B4 production by leukocytes in vitro at the concentration of about $30 \mu \mathrm{g} / \mathrm{ml}$. In this study, to analyse the effects of acanthoic acid on TNF- $\alpha$ production further, we tested it on TNF- $\alpha$ gene expression and haptoglobin production regulated by TNF- $\alpha$.

\section{Materials and Methods}

\section{Preparation of acanthoic acid}

Acanthoic acid was isolated essentially as described previously. ${ }^{7}$ Usually, more than $95 \%$ pure acanthoic acid was obtained by fractionation on a silica-gel column chromatography ( $n$-hexane-ethylacetate, 20:1 to $5: 1$ ).

\section{Isolation of human monocytes/macrophages}

Heparinized blood obtained from healthy donors was overlayered on a Ficoll-Hypaque density gradient and centrifuged at $700 \times \boldsymbol{g}$ for $30 \mathrm{~min}$. Mononuclear cells and neutrophils were obtained at the density of $1.077 \mathrm{~g} / \mathrm{l}$ and of $1.077-1.119 \mathrm{~g} / \mathrm{l}$ respectively. Mononuclear cells were incubated in a $24-w$ ell culture plate for $2 \mathrm{~h}$ and adherent monocytes/macrophages ( $>90 \%$ purity by non-specific esterase staining) were obtained. Then the cells were preincubated with various concentrations of acanthoic acid for $1 \mathrm{~h}$ and stimulated with $100 \mu \mathrm{g} / \mathrm{ml}$ silica. After $48 \mathrm{~h}$ incubation, the culture supernatants were assayed for TNF- $\alpha$ using a TNF- $\alpha$ ELISA kit obtained from Genzyme (Cambridge, MA).

\section{Transfection of TNF- $\alpha$ CAT construct}

HeLa cells $\left(5 \times 10^{5}\right.$ cells/sample $)$ were transfected with $10 \mu \mathrm{g}$ TNF- $\alpha$ promoter-CAT reporter plasmid 

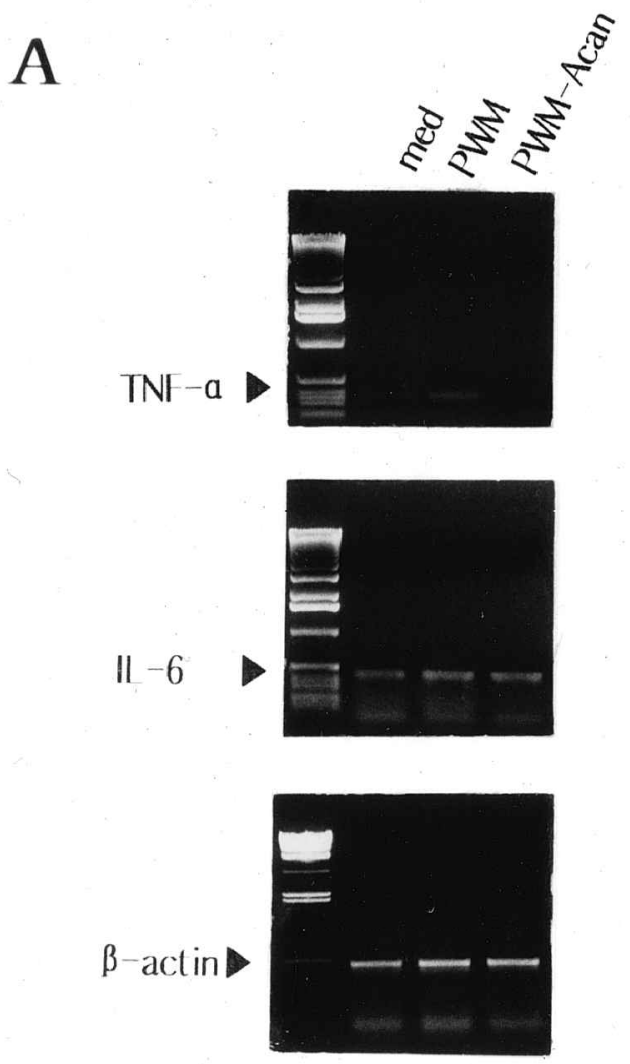

B

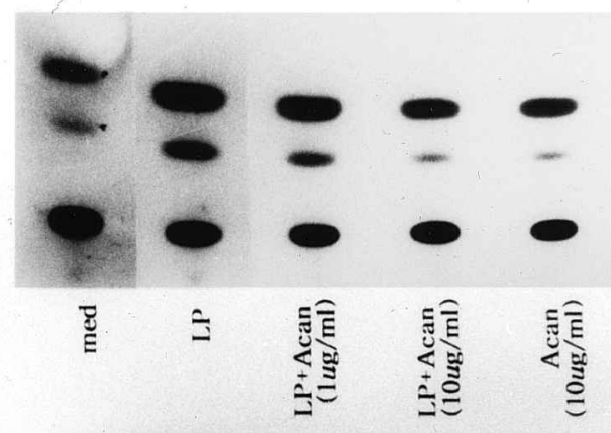

C

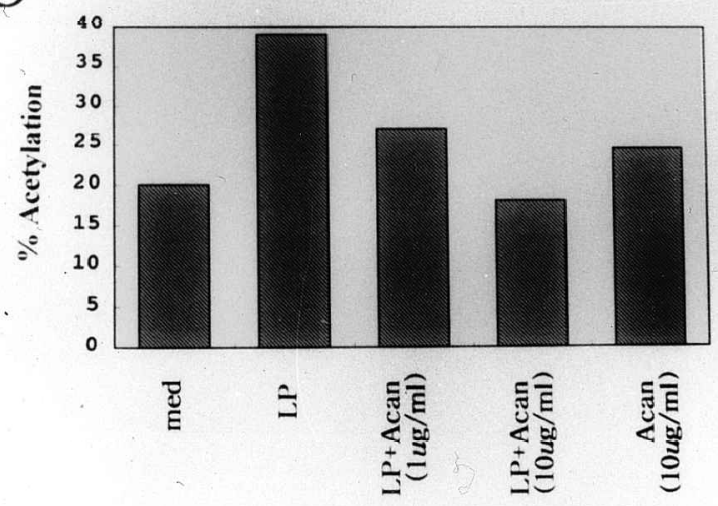

FIG. 1. Acanthoic acid inhibited TNF- $\alpha$ gene expression (A) Human monocytes/macrophages $\left(1 \times 10^{6}\right.$ cells/well $)$ were incubated with $10 \mu \mathrm{g} / \mathrm{ml}$ of acanthoic acid for $1 \mathrm{~h}$ and stimulated with $10 \mu \mathrm{g} / \mathrm{ml}$ PWM. Then RT-PCR was performed using specific primers. (B) HeLa cells $\left(5 \times 10^{5}\right.$ cells/sample) were transfected with $10 \mu \mathrm{g}$ TNF- $\alpha$ promoter-CAT reporter plasmid using calciumphosphate method. After $16 \mathrm{~h}$ incubation, cells were treated with $10 \mu \mathrm{g} / \mathrm{ml}$ LPS plus $100 \mathrm{ng} / \mathrm{ml}$ PMA for $18 \mathrm{~h}$ in the presence or absence of acanthoic acid. Then $10 \mu \mathrm{g}$ of cell lysates were assayed for CAT activity. (C) The CAT activity was calculated as follows: $\%$ acetylation $=(\mathrm{cpm}$ in acetylated species $/ \mathrm{cpm}$ in acetylated species + non-acetylated chloramphenicol $) \times 100$.

using calcium-phosphate method. After $16 \mathrm{~h}$ incubation, cells were treated with $10 \mu \mathrm{g} / \mathrm{ml}$ LPS plus $100 \mathrm{ng} / \mathrm{ml}$ PMA for $18 \mathrm{~h}$ in the presence or absence of acanthoic acid. Then $10 \mu \mathrm{g}$ of cell lysates were assayed for CAT activity. The CAT activity was calculated as follows: acetylation rate $=(\mathrm{cpm}$ in acetylated species/cpm in acetylated species + nonacetylated chloramphenicol).

\section{Results and Discussion}

Previous results showed that acanthoic acid inhibited TNF- $\alpha$ production from human monocytes/macrophages stimulated with $100 \mu \mathrm{g} / \mathrm{ml}$ silica. Several diterpene compounds having similar structures isolated from the root bark of Acanthopanax koreanum were tested for inhibiting TNF- $\alpha$ synthesis. Acanthoic acid significantly inhibited TNF- $\alpha$ production from human monocytes/macrophages $(73.4 \pm 7.9 \%$ inhibition compared with untreated control), but other diterpenes had no effects on TNF- $\alpha$ production (data not show $n$ ). It also suppressed TNF- $\alpha$ production in the sera of experimental silicosis rats $(79.5 \pm 1.4 \%$ inhibition compared with untreated silicosis rats).
To know the molecular action of acanthoic acid on TNF- $\alpha$ synthesis, the effects of acanthoic acid on TNF$\alpha$ gene expression were tested. Acanthoic acid suppressed PWM-induced TNF- $\alpha$ gene expression in human monocytes/macrophages (Fig. 1A). But it had no effects on the gene expression of IL- 6 and $\beta$-actin. Furthermore, acanthoic acid suppressed the promoter activity of TNF- $\alpha$ activated with LPS and PMA (Fig. 1B,C). $10 \mu \mathrm{g} / \mathrm{ml}$ acanthoic acid inhibited about $50 \%$ of LPS and PMA-induced TNF- $\alpha$ promoter activity.

TNF- $\alpha$ is involved in hepatic inflammation and fibrosis. In the liver, TNF- $\alpha$ induces a group of acute phase proteins including haptogloin. ${ }^{10}$ Haptoglobin is related to the status of inflammation, infection and malignancy. ${ }^{11-13}$ So we tested the effects of acanthoic acid on haptoglobin synthesis of hepatocytes. TNF- $\alpha$ inhibited haptoglobin synthesis of Hep3B cells stimulated with LPS and PMA (Fig. 2), but it had no effects on Hep3B cell proliferation (data not shown).

Acanthoic acid is a diterpene isolated from Acanthopanax koreanum. It has anti-inflammatory effects in vivo and in vitro. In this study, it is demonstrated 


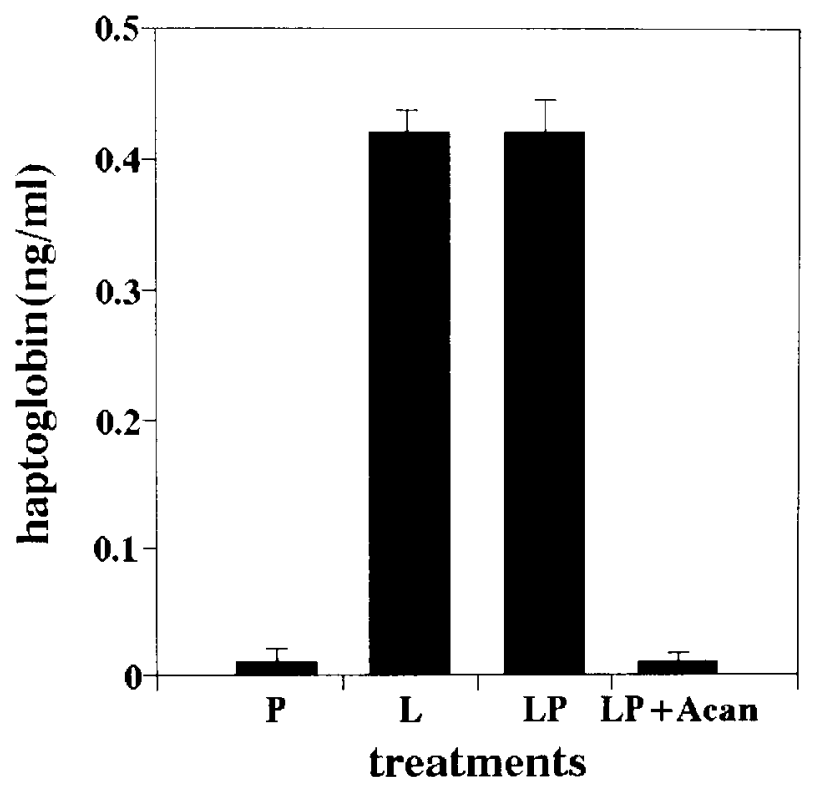

FIG. 2. Acanthoic acid inhibited haptoglobin synthesis from Hep3B cells. Hep3B cells $\left(4 \times 10^{4}\right.$ cells/well) were starved in a serum-free RPMl 1640 medium for overnight at $37^{\circ} \mathrm{C}$. Then the cells were washed with serum-free RPMl 1640 medium. The cells were preincubated with $10 \mu \mathrm{g} / \mathrm{ml}$ acanthoi $c$ acid for $1 \mathrm{~h}$ and stimulated with $10 \mu \mathrm{g} / \mathrm{ml}$ LPS and/or $100 \mathrm{ng} / \mathrm{ml}$ PMA. After $48 \mathrm{~h}$ incubation, the culture supernatants were assayed for haptoglobin production using haptoglobin ELISA. Data represent the mean \pm SD of four different determinants.

that the main intracellular target of acanthoic acid is machinery of TNF- $\alpha$ gene expression. The exact target molecule which interacts with acanthoic acid needs to be defined. Considering its action of mechnism, it will be used as an anti-inflammatory agent to treat many inflammatory diseases.

\section{References}

1. Ruddle NH. Tumor necrosis factor (TNF-alpha) and lymphotoxin (TNFbeta). Curr Opin Im munol 1992; 4: 327-332.

2. Douni EK, Akassoglou L, Alex opoulou S, Georgolpouolos S, Haralambous S, Kollias G, Kontoyiannis D, Pasparakis M, Plow s D, Probert L, Kollias G. Transgenic and knockout analysis of the roles of TNF in immune regulation and disease pathogenesis. J Inflamm 1995; 45: 27-38.

3. Schmitz H, Fromn M, Bode H, Scholz P, Riecken EO, Schulzke JD. Tumor necrosis factor-alpha induces $\mathrm{CL}^{-}$and $\mathrm{K}^{+}$secretion in human distal colon driven by prostaglandin $\mathrm{E}_{2}$. Am J Physiol 1996; 271: 669-674.

4. Ross SE, Williams RO, Mason LJ, Mauri C, Marinova-Mutafchieva L, Malfait A, Maini RN, Feldmann M. Suppression of TNF- $\alpha$ ex pression, inhibition of Th 1 activity, and amelioration of collagen 0 induced arthritis by rolipram. J Imm unol 1997; 159: 6253-6259.

5. Mullighan CG, Fanning GC, Chapel HM, Welsh KI. TNF and lymphotoxin$\alpha$ polymorphisms associated with common variable immunodeficiency: role in the pathogenesis of granulomatous disease. J Im munol 1997; 159: 6236-6241.

6. Rabinovitch A, Suarez-pinzon WL, Sorensen O, Rajotte RV, Power RF.TNF$\alpha$ down-regulates type 1 cytokines and prolongs survival of syngeneic islet grafts in nonobese diabetic mice. J Immunol 1996; 159: 6298-6303.

7. Kim YH, Chung BS. Pimaradiene diterpenes from Acanthopanax koreanum. J Nat Prod 1988; 51: 1080-1083.

8. Lee YS. Pharmacological studies of (-)-pimara-9(11), 15-dien-19-oic acid isolated from Acanthopanax koreanum. PhD dissertation Seoul National Unive rsity, 1990.

9. Kang HS, Kim YH, Lee CS, Lee JJ, Choi I, Pyun KH. Suppression of interleukin- 1 and tumor necrosis factor- $\alpha$ production by acanthoic acid, (-)-pimara-9(11), 15-dien-19-oic acid, and its antifibrotic effects in vivo. Cell Im munol 1996; 170: 212-221.

10. Nakagawa-Tosa N, Morimatsu M, Kawasaki M, Syuto B, Saito M. Stimulation of haptoglobin synthesis by interleukin-6 and tumor necrosis factor, but not by interleukin-1, in bovine primary cultured heptocytes. J Vet Med Sci 1995; 57: 219-223.

11. Dobryszycka W. Biological functions of haptoglobin-new pieces to an old puzzle. Eur J Clin Chem Clin Biochem 1997; 35: 647-654.

12. Cid MC, Grant DS, Hoffman GS, Auerbach R, Fauci AS, Kleinman HK. Identification of haptoglobin as an angiogenic factor in sera from patients with systemic vasculitis. J Clin Invest 1993; 91: 977-985.

13. Friedrichs WE, Navarijo-Ashbaugh AL, Bow man BH, Yang F. Expression and inflammatory regulation of haptoglobin gene in adipocytes. Biochem Biophys Res Commun 1995; 209: 250-256.

ACKNOWLEDGEMENTS. This work was supported by grants HAN project HS 1630 and KG1093 from MOST, Republic of Korea.

Received 18 February 1998; accepted 23 March 1998 


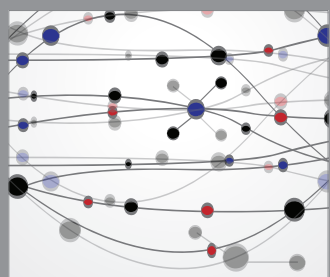

The Scientific World Journal
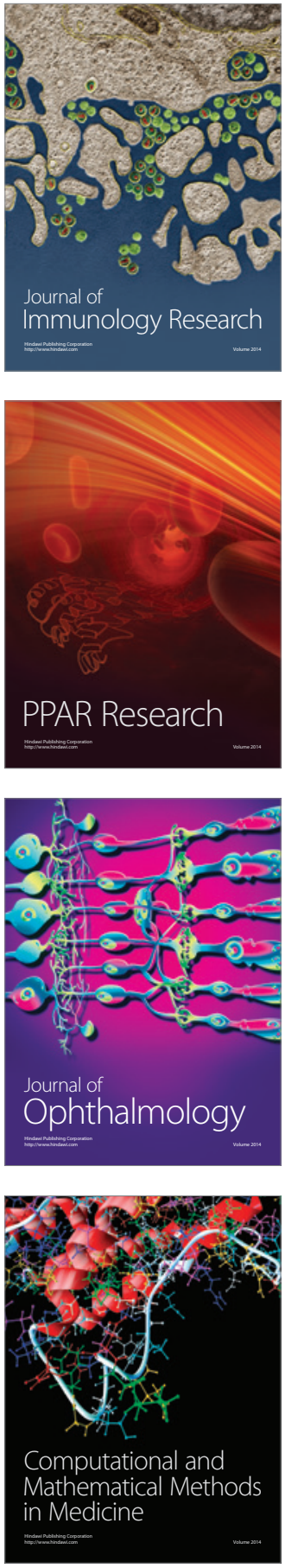

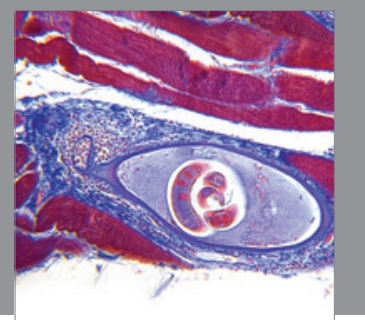

Gastroenterology

Research and Practice
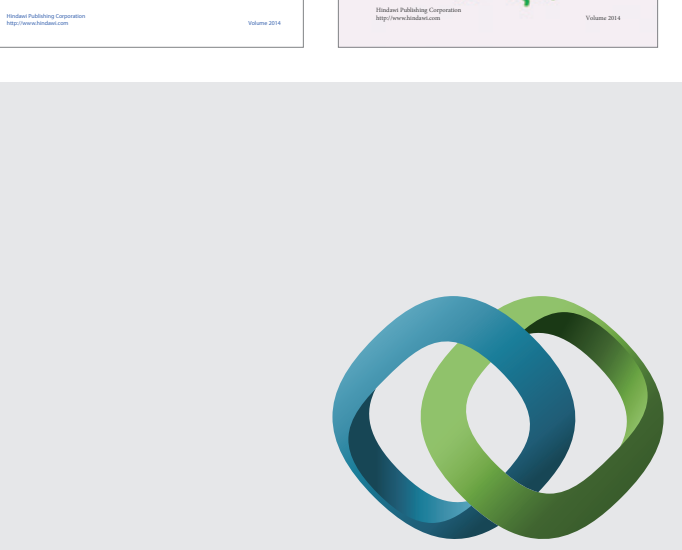

\section{Hindawi}

Submit your manuscripts at

http://www.hindawi.com
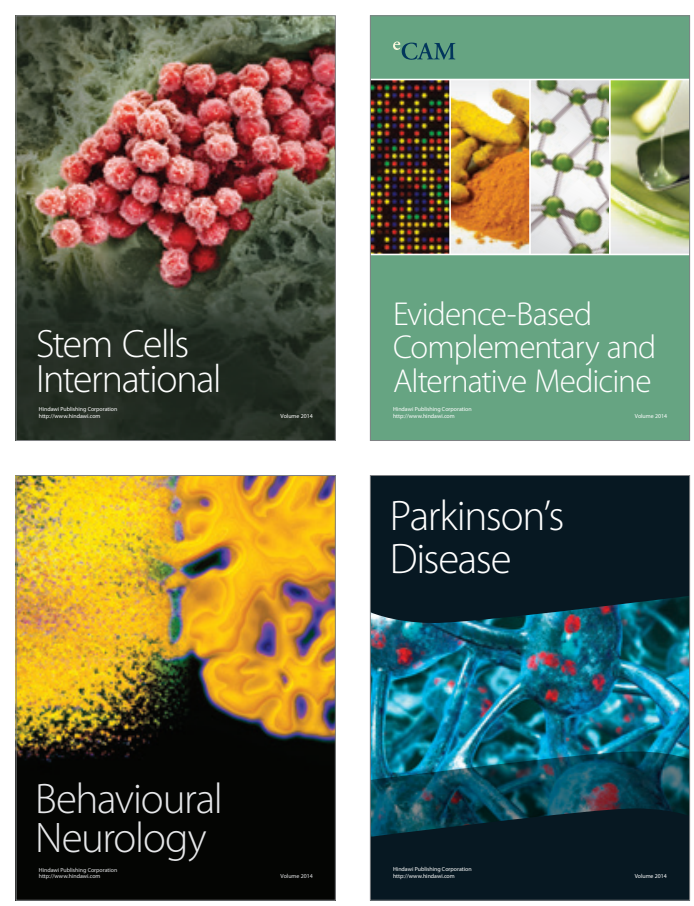

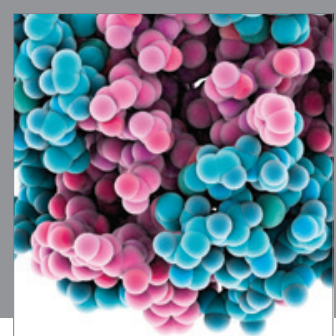

Journal of
Diabetes Research

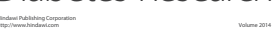

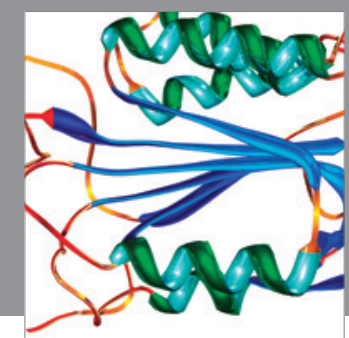

Disease Markers
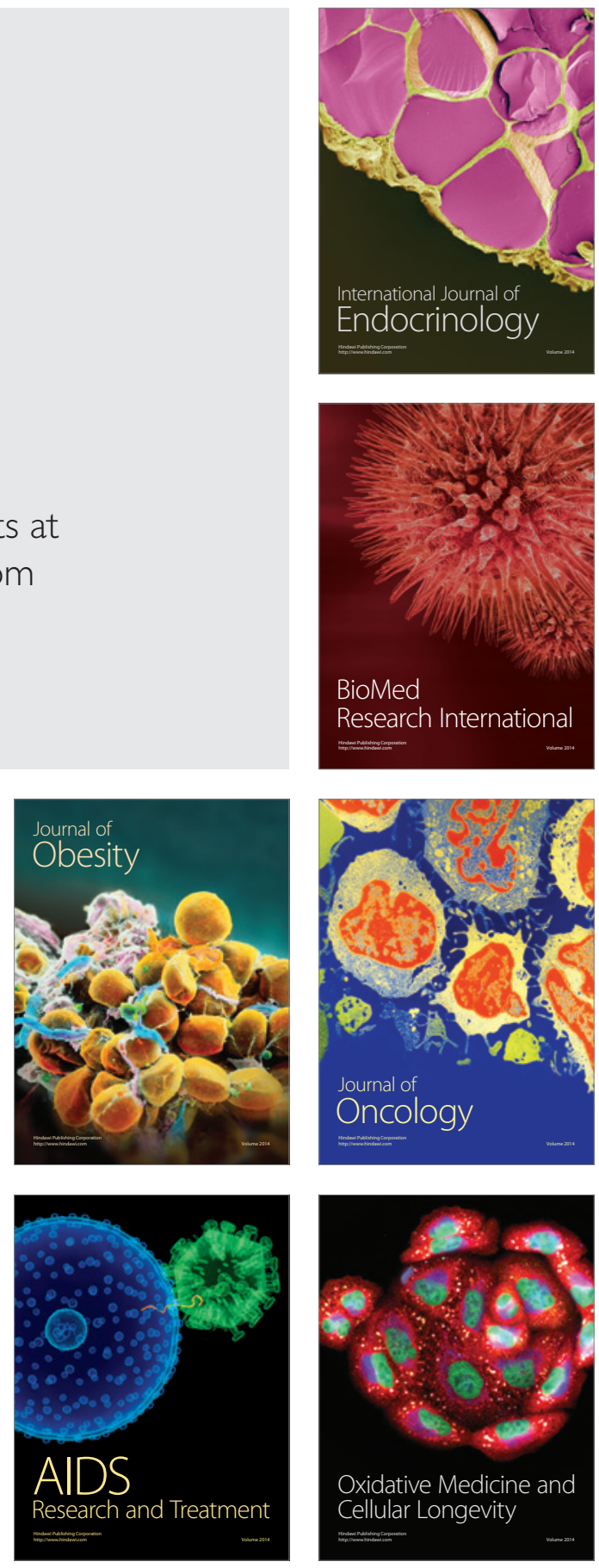